\title{
A COMPARATIVE STUDY ON EFFECTIVENESS OF DIFFERENT STATISTICAL TECHNIQUES - WITH SPECIAL REFERENCE TO AUTOMOBILE BUYING DECISIONS
}

\author{
Dr.M.Kannan \\ Assistant Professor \\ Department of Computer Science and Applications \\ SCSVMV University, Enathur, Kanchipuram-631561
}

\author{
Dr.N.Ashok Kumar \\ Assistant Professor \\ Department of Electrical \& Electronics Engineering \\ SCSVMV University, Enathur, Kanchipuram-631561
}

\begin{abstract}
Different sort of statistical tools and packages are used widely used for different cases. These case results are elaborately analyzed by researchers. Each and every statistical technique has their own strong points as well as weakness. This paper focuses on a in-depth analysis on the effectiveness of the different statistical techniques like factor analysis, correlation, regression and some of the mining techniques. The problem scenario taken for the testing the result is automobile buying decisions in Kanchipuram.
\end{abstract}

Keyword : Statistical tools, Factor analysis, Correlation, Regression, Mining techniques

\section{INTRODUCTION}

Earlier many research papers are presented based on statistical techniques and their effectiveness. In our earlier papers [1][2], SPSS 19.0 and Weka tool was effectively deployed and results were presented. The same paper has been the motive and it is extended in a different scenario. These sort of studies will definitely be a guidance for the persons in supply chain management right from the producer end down to the consumer end. All are get benefited particularly the dealers in this industry the retail end show room operators and finally the consumer. So in that way this study is more oriented to the social environment.

\section{LITERATURE REVIEW}

Dr. Ronald Mani \& Mr. Debasis Tripathy [3] conducted a study from 300 customers using random sampling technique to understand the influencing factors for purchasing two wheeler buying behavior in Uttar Pradesh. The study reveals that customers are satisfied with Honda and Bajaj company vehicles. K. P Najeemudeen \& N. Panchanatham [4] conducted a survey from 681 two wheeler consumers in Malappuram district of Kerla to understand the information sources for procuring their choice of two wheelers. A. Martin Jayaraj [5] conducted a study from 128 respondents in Coimbatore district using descriptive in nature to understand the awareness, influencing factors and reasons to choose particular dealer for their choice of buying two wheeler vehicles.

S.Suraj Basha \& Dr.B.C.Lakshmanna [6] identified that personal factors have significant impact in purchasing decision. Dr. Priyadarshini Padhi [7] conducted a study from 110 consumers from Ganjam to meet out the objectives of the study. The result reveals that family members play a vital role in purchase decision. Effective sales promotion leads to selecting particular brand.

A. Anandalakshmy \& Dr. K. Brindha [8], conducted a study from 150 respondents in Coimbatore city using convenient random sampling method and result reveals that majority of the women prefer scooty pep plus vehicle for the reason that smooth in running. Also colour and model leads to preference in choosing the vehicles.

\section{OBJECTIVES OF THE STUDY}

The main objective of the study is to analyze

$>$ Effectiveness of the strength and weakness of various statistical tools.

$>$ To present the snapshot about the automobile sector in Kanchipuram to the supply chain management group.

\section{METHODOLOGY}

In our earlier paper different sort of target questions were presented to different consumer groups and data were obtained. These data were sorted by mean analysis. And over this, SPSS 19 and Weka tool were tested. In this extended work, methodology were adopted to collect data and to normalize it. Over this normalized result, the effectiveness of various techniques like factor analysis, correlation, regression and mining techniques are applied and it was deeply analyzed.

\section{RESULTS \& DISCUSSION}

\subsection{Factor Analysis}

The unique feature of this research work is that for the authentication for producing factor analysis or in another way dimension reduction has to be proved beyond doubt. For that we have chosen KMO \& Barlett's test, from the table $1 \& 3$, the significant value is less than 0.05 which indicates that we can proceed for dimension reduction. 
Table 1: Reasons to choose particular company

Kaiser-Meyer-Olkin Measure of Sampling Adequacy.

Bartlett's Test of Approx. Chi-Square Sphericity df Sig.

Table 2: Rotated Component Matrix - Particular Company

\begin{tabular}{|l|r|r|r|r|r|}
\hline & \multicolumn{5}{|c|}{ Component } \\
\cline { 2 - 6 } & \multicolumn{1}{c|}{1} & \multicolumn{1}{c|}{2} & \multicolumn{1}{c|}{3} & \multicolumn{1}{c|}{4} & \multicolumn{1}{c|}{5} \\
\hline Word of mouth & .743 & .090 & .191 & .087 & -.298 \\
\hline $\begin{array}{l}\text { Finance/loan } \\
\text { arrangement }\end{array}$ & .703 & -.209 & .053 & -.317 & .408 \\
\hline Loyalty & -.615 & -.158 & .341 & -.152 & .101 \\
\hline Availability & .006 & .757 & .040 & -.314 & -.209 \\
\hline Insurance & .127 & .674 & -.175 & .117 & .259 \\
\hline Infrastructure & -.107 & .514 & .503 & .310 & .238 \\
\hline $\begin{array}{l}\text { Exchange } \\
\text { offers }\end{array}$ & .025 & -.067 & .869 & -.071 & -.160 \\
\hline $\begin{array}{l}\text { Service and } \\
\text { support }\end{array}$ & .022 & .025 & -.192 & .747 & .023 \\
\hline $\begin{array}{l}\text { Company } \\
\text { Image }\end{array}$ & .035 & -.119 & .365 & .576 & .026 \\
\hline $\begin{array}{l}\text { Affordable } \\
\text { Price }\end{array}$ & -.128 & .094 & -.077 & .060 & .843 \\
\hline $\begin{array}{l}\text { Source: Primary } \\
\text { Inyyyyy}\end{array}$ & & & & \\
\hline
\end{tabular}

Source: Primary data

Table 3: Reasons to choose particular vehicle

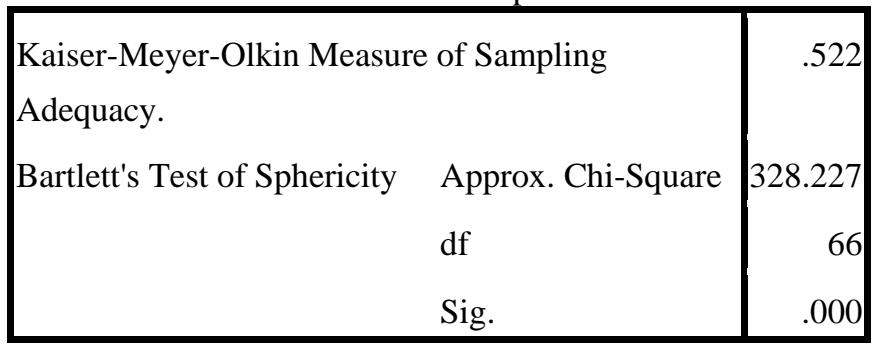

Table 4: Rotated Component Matrix - Particular Vehicle

\begin{tabular}{|l|r|r|r|r|c|}
\hline \multirow{2}{*}{} & \multicolumn{5}{|c|}{ Component } \\
\cline { 2 - 6 } & 1 & \multicolumn{1}{c|}{2} & \multicolumn{1}{c|}{3} & \multicolumn{1}{c|}{4} & \multicolumn{1}{c|}{5} \\
\hline Durability & .720 & .025 & .075 & -.193 & -.088 \\
\hline $\begin{array}{l}\text { Less } \\
\text { maintenance }\end{array}$ & .620 & -.465 & -.380 & .085 & .028 \\
\hline Style & .588 & .093 & -.199 & .138 & .286 \\
\hline Brand image & .527 & .100 & .363 & .115 & .199 \\
\hline Pickup & -.001 & .763 & .241 & .167 & .067 \\
\hline Luggage space & -.067 & -.659 & .534 & .174 & .029 \\
\hline
\end{tabular}

\begin{tabular}{|l|r|r|r|r|r|}
\hline $\begin{array}{l}\text { and seat } \\
\text { comfort }\end{array}$ & & & & & \\
\hline Outlook & .463 & .478 & -.014 & .329 & -.131 \\
\hline Color & .008 & -.097 & -.784 & .071 & .003 \\
\hline Speed & -.173 & -.070 & -.074 & .811 & -.071 \\
\hline Mileage & .288 & .272 & .078 & .692 & .034 \\
\hline Resale value & .199 & .020 & .131 & -.031 & .847 \\
\hline Price & .427 & .060 & .332 & .095 & -.515 \\
\hline
\end{tabular}

Source: Primary data

Accordingly we proceeded for factor analysis to consolidate the most crucial factors which are influencing the buyer's attitude for selecting their two wheeler brands. The most crucial factors are highlighted in the table 2.

Initially we chosen 10 factors, on applying the varimax rotation technique it has been reduced to 5 crucial factors. From the component 1 , three factors have been taken say word of mouth, finance/loan arrangement and loyalty for analysis. If we crucially look into these factors all can be club together as "Benevolent attitude of the dealer". This component induces strongly towards customer for their buying decision. In component 2, availability, insurance and infrastructure, this can be clustered as "Access to facilities". So the customer really needs to have good infrastructure and availability at any point of time. Under component 3, we have infrastructure and exchange offers, this can be clubbed together as "Value addition benefits". Any customer is much happy if they gets good amount of money from their old two wheeler and if its offered as good exchange price, their buying decision are much attracted. In component 4 , we have service support and company image, this can be grouped as "After sales care”, customers are delighted when he/she has a amicable after sales care for their two wheelers. This is having more influenced in their buying decision. Component 5, we have affordable price which can be put as "Motivational factor". This factor is named for the reason there is a say, "No other better motivation than money", money is the best motivation factor, so if customer gets a decent saving and quality product is afford to him/her of a competitive price he/she is much happy. Finally we conclude that we have 5 components, benevolent attitude of dealer, access to facilities, value addition benefits, after sales care and motivational factor, by this approach we have clustered different factors under 5 components.

From the table 4 we have reduced 12 factors into 5 components to understand the reasons to choosing particular vehicle. Component 1 can be named as "Trouble freeness", component 2 can be named as "Additional benefit factor", component 3 can be called as "Comfortability", component 4 can be clustered as "Technical supremacy" and component 5 can be called as "Value for money".

The strength of factor analysis technique is to reduce number of variables into components and to identify groups of inter-related variables. The weakness is difficult to pick proper rotation and interpretation is heuristic approach.

\subsection{Correlation}

From the table 5, clearly indicates that there is a significant correlation and it is diagonally symmetrical. This table clearly signifies the correlation connectivity among various factors. Advantage of correlation method is that it shows the 
strength of relationship between two variables either positive or negative. A disadvantage is that it does not reveal cause and effect.

Table 5: Correlation between reasons to choose particular company

\begin{tabular}{|l|l|l|l|l|l|l|l|l|l|l|}
\hline & a & b & c & d & e & f & g & h & i & j \\
\hline a & 1 & & & Sig & & & & & & \\
\hline b & & 1 & Sig & & & & & & & \\
\hline c & & & 1 & Sig & & Sig & & & & Sig \\
\hline d & & & Sig & 1 & & & & Sig & & \\
\hline e & & & & & 1 & & & & & \\
\hline f & & & & & & 1 & Sig & & & Sig \\
\hline g & & & & & & Sig & 1 & & & \\
\hline h & & & & Sig & & & & 1 & Sig & \\
\hline i & & & & & & & & Sig & 1 & \\
\hline j & & & Sig & & & Sig & & & & 1 \\
\hline
\end{tabular}

Note : a-Company image, b-Affordable price, c-Exchange offers, d-Infrastructure, e-Service and support, f-Word of mouth, g-Finance/loan arrangement, h-Insurance, iAvailability, j-Loyalty

Table 6: Correlation between reasons to choose particular vehicle

\begin{tabular}{|l|l|l|l|l|l|l|l|l|l|l|l|l|}
\hline & a & b & c & d & e & f & g & h & i & j & k & l \\
\hline a & 1 & & S & & & & S & S & & & & S \\
\hline b & & 1 & S & & & & S & & S & & & \\
\hline c & S & S & 1 & S & S & & & & & & & S \\
\hline d & & & S & 1 & & S & & & & S & & S \\
\hline e & & & S & & 1 & & & & & & & \\
\hline f & & & & S & & 1 & S & S & S & & & \\
\hline g & S & S & & & & S & 1 & & & & & S \\
\hline h & S & & & & & S & & 1 & & & S & S \\
\hline i & S & S & & & & S & & & 1 & & & \\
\hline j & & & & S & & & & & & 1 & & S \\
\hline k & & & & & & & & S & & & 1 & \\
\hline l & S & & S & S & & & S & S & & S & & 1 \\
\hline
\end{tabular}

Note : a-Brand image, b-Price, c-Mileage, d-Pickup, eSpeed, f-Less maintenance, g-Durability, h-Style, i-Color, jLuggage space and seat comfort, k-Resale value, l-Outlook \& S - Significant

\subsection{Regression Analysis}

From the regression analysis table 7, significant value is less than 0.05 , hence model is valid and proceed for further analysis. It is observed from table 8 factor such as affordable price, word of mouth and availability is having strong impact in buying decision. This table is particularly applied for choosing a particular company for buying their two wheeler vehicle. This regression table is formed with specific approach towards choosing the company. It should be appreciated that here the approach is more specific than generic. Advantage of regression analysis is to examine relationship between dependent variable and several independent variables. Disadvantage is it cannot be used in qualitative phenomenon.

Table 7 : ANOVA

\begin{tabular}{|l|l|r|c|}
\hline \multicolumn{1}{|c|}{ Model } & \multicolumn{1}{|c|}{ Sum of Squares } & F & Sig \\
\hline $\begin{array}{l}\text { Regression } \\
\text { Residual }\end{array}$ & 7.839 & 3.818 & .000 \\
\hline
\end{tabular}

Table 8: Coefficient value Choosing particular company

\begin{tabular}{|l|c|}
\hline & Significant \\
\hline (Constant) & .000 \\
\hline Company Image & .906 \\
\hline Affordable Price & .004 \\
\hline Exchange offers & .241 \\
\hline Infrastructure & .477 \\
\hline Service and support & .290 \\
\hline Word of mouth & .004 \\
\hline Finance/loan arrangement & .175 \\
\hline Insurance & .738 \\
\hline Availability & .036 \\
\hline Loyalty & .330 \\
\hline
\end{tabular}

Source: Primary data

From the regression analysis table 9 it is understood that model is valid and it can be proceed for further analysis. It is found from table 10, factor as brand image, speed, luggage space and seat comfort having strong impact in buying specific two wheeler decision.

Table 9 : ANOVA

\begin{tabular}{|l|c|c|c|}
\hline Model & Sum of Squares & F & Sig \\
\hline Regression & 25.247 & 19.065 & .000 \\
Residual & 19.753 & & \\
\hline
\end{tabular}

Table 10: Coefficient value -

Choosing particular two wheeler

\begin{tabular}{|l|c|}
\hline & Significant \\
\hline (Constant) & .000 \\
\hline Brand image & .020 \\
\hline Price & .228 \\
\hline Mileage & .274 \\
\hline Pickup & .288 \\
\hline Speed & .000 \\
\hline Less maintenance & .477 \\
\hline Durability & .583 \\
\hline Style & .990 \\
\hline Color & .272 \\
\hline Luggage space and seat comfort & .000 \\
\hline Resale value & .605 \\
\hline Outlook & .268 \\
\hline
\end{tabular}

Source: Primary data

\subsection{Classification Techniques \& Clustering Techniques}

Table 11 depicts different classification methods such as naive bayes and bayes net, it reveals that naive bayes method is better than bayes net through correctly classified 
instances. Table 12 shows different clustering methods such as simple k-means and hierarchical. Cluster 0 belongs to motor bike category and cluster 2 belongs to scooters category.

Table 11: Classification Methods

\begin{tabular}{|c|c|}
\hline $\begin{array}{l}\text { Naive Bayes } \\
\text { Classification }\end{array}$ & $\begin{array}{l}\text { Correctly } \text { Classified Instances } \\
173 \quad 90.1042 \% \\
\text { Incorrectly } \\
\begin{array}{ll}19 & \text { Classified Instances } \\
9.8958 \%\end{array}\end{array}$ \\
\hline Bayes Net & 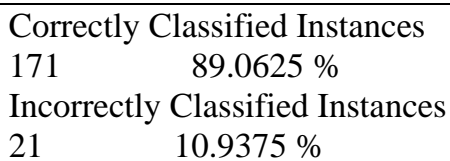 \\
\hline
\end{tabular}

Table 12: Clustering Methods

\begin{tabular}{|l|lc|l|}
\hline Simple & \multicolumn{2}{|l|}{ Clustered } & Cluster $0<-$-- MOTOR \\
K-Means & \multicolumn{2}{|l|}{ Instances } & BIKE \\
& 0 & $117(61 \%)$ & Cluster $1<--$ \\
& 1 & $75(39 \%)$ & SCOOTERS \\
\hline $\begin{array}{l}\text { Hierarchical } \\
\text { cluster }\end{array}$ & 0 & $188(98 \%)$ & Cluster $0<-$ MOTOR \\
& 1 & $4(2 \%)$ & BIKE \\
& & & Cluster $1<-$-- No class \\
\hline
\end{tabular}

\section{CONCLUSION}

In this research article, various statistical techniques like factor analysis, correlation, regression and some of the mining techniques like classification and clustering have been applied for specific issue of knowing buyers attitude for two wheeler selection in and around Kanchipuram town. The results are already discussed in detail. The researcher's has to appreciate the fact that each technique is having efficacy in certain critical factors. So much more such statistical tools can be engaged over more specific socio economic problems which will be more much useful for both researcher as well as for business people and also for customers. This research has to be appreciate for getting defined results for the specific problem by three different statistical methodology and mining techniques.

\section{REFERENCES}

1. Dr. M. Kannan \& S. Suriyanarayanan, "An observational study on two wheeler buying choice", International Journal of Advanced Engineering Research and Science (IJAERS), ISSN: 2456-1908, Vol-3, Issue-12, Dec- 2016, pp.213-217.

2. Dr.M.Kannan \& S.Suriyanarayanan, "A study on two wheeler purchasing decision using data mining techniques” is presented in International conference on recent trends in computing technology, organized by Dept of computer applications, Bharath University, Chennai on 21-April 2017.

3. Dr. Ronald Mani \& Mr. Debasis Tripathy, "A study on consumer buying behavior towards two wheeler bikes in context to Indian market”, International Journal of Advanced Research in Management (IJARM), ISSN 0976 - 6332, Volume 4, Issue 1, January- April 2013, pp.65-73.

4. K. P Najeemudeen \& N. Panchanatham, "Information Sources for Two-wheeler Purchase: An Analytical Study with Special Focus on Malappuram District of Kerala”, Universal Journal of Industrial and Business Management, 4(2): 2016, pp.59-70.

5. A. Martin Jayaraj, “A study on consumer behaviour towards two wheeler dealers in Coimbatore district", International Journal of Management Research \& Review, ISSN: 2249-7196, Volume 7, Issue 4, 2017, pp.418-423.

6. S.Suraj Basha \& Dr.B.C.Lakshmanna, "A study on factors influencing consumer's buying behavior of two wheelers with special reference to Rayalaseema region, Andhra Pradesh, India”, International Journal of Academic Research, ISSN: 2348-7666; Vol.4, Issue-4(1), April, 2017, pp.37-49

7. Dr. Priyadarshini Padhi, "Decision making process for durable products: A case study of two-wheelers in Ganjam", International Journal of Research in Finance and Marketing, Vol. 7 Issue 5, 2017, pp. 63-70.

8. Anandalakshmy \& Dr. K. Brindha, "Women's preference of two wheelers with special reference to Coimbatore city", International Journal of Current Research and Modern Education, ISSN 2455 - 5428, Volume 2, Issue 1, 2017, pp.7984. 